Review

\title{
Role of tea catechins in prevention of aging and age-related disorders
}

\author{
Arjun Khanna, Pawan Kumar Maurya* \\ Amity Institute of Biotechnology, Amity University, India
}

\begin{abstract}
Tea polyphenols especially catechins have long been studied for their antioxidant and radical scavenging properties. Scientists throughout the world have investigated the usefulness of the regular green tea consumption in several disease conditions. In-vitro and in-vivo experiments on catechins especially epigallocatechingallate have revealed a significant role in many ways. Reactive oxygen species have been increasingly implicated in the pathogenesis of many diseases and important biological processes. Toxic effects of these oxidants, commonly referred to as oxidative stress, can cause cellular damage by oxidizing nucleic acids, proteins, and membrane lipids. Oxidative stress has been related to aging and age related disorders. It is found that in a wide variety of pathological processes, including cancer, atherosclerosis, neurological degeneration, Alzheimer's disease, ageing and autoimmune disorders, oxidative stress has its implications. Catechins have been reported to be useful in combating aging and age related disorders like cancer, cardiovascular disorders and neurodegenerative diseases. In this mini review we will discuss such studies done across the globe.
\end{abstract}

Keywords tea catechins, aging, oxidative stress, age-related disorders

\section{INTRODUCTION}

Tea is a popular beverage prepared from the leaves of Camellia sinensis worldwide. Three main types of tea, viz. green tea, black tea, and oolong tea are manufactured from its leaves. Historically, tea has been a widely consumed beverage among Chinese and other Asian populations. The health benefits in several inflammatory and age related disorders have led to increased popularity of tea especially green tea. These beneficial effects are attributed to the flavonoids found in green tea i.e. catechins (Graham, 1992). Tea catechins or green tea catechins (GTC) are major polyphenols present in green tea and include (-) epicatechin (EC); (-) epicatechin gallate (ECG); ()epigallocatechin (EGC) and (-)epigallocatechin gallate (EGCG). During the manufacturing process of black tea and oolong tea these catechins get oxidized to form orange-red pigments, theaflavins (TF) (Subramanian et al., 1999). The catechins possess antioxidant properties (van Acker et al., 1996) that make them helpful against reactive oxygen species (ROS) and oxidative stress (OS) in a number of pathological conditions viz. cardiovascular diseases including hypertension, neurodegenerative disorders, atherosclerosis, cancer, inflammation and aging (Maurya et al., 2009; Gutteridge, 1993).

A small percentage of the oxygen we inhale gets converted to $\mathrm{ROS}$ viz. $\mathrm{O}_{2}^{-}, \mathrm{H}_{2} \mathrm{O}_{2}$, and $\cdot \mathrm{OH}$ (Harman, 1993) which can cause OS resulting in damage to the ionic parameters (Maridonneau et al., 1983), membrane bound receptors and enzymes (Halliwell and Gutteridge, 1986), lipoproteins (Steinberg et al., 1989), DNA (Wiseman and Halliwell, 1996), etc. These ROS are handled by the cellular antioxidant systems. But in the case of an imbalance between ROS production and

\footnotetext{
*Correspondence: Pawan Kumar Maurya

E-mail: pawan_biochem@yahoo.co.in

Received July 2, 2011; Accepted February 13, 2012; Published

February 29, 2012

doi: http://dx.doi.org/10.5667/tang.2011.0016

(C)2012 by Association of Humanitas Medicine
}

TANG / www.e-tang.org the antioxidant defence system, several pathological conditions including premature aging arise. Recently, the pineal hormone, melatonin, having antioxidant properties, has been related to the aging process and has been shown to decrease with age (Reiter et al., 1998), further slowing the decline in antioxidant capacity with age and making our system more prone to age related disorders. In the following manuscript, there will be a discussion of studies related to catechins and aging and age related disorders viz. neurodegenerative disorders, cancer and cardiovascular disorders. About $80 \%$ population of Asian and African countries depends on traditional medicine for primary health care. Traditional medical system helps us in understanding the laws and pattern of nature. The objective of this review is to discuss the role of tea catechins in prevention of aging and age related disorders.

\section{Catechins}

Catechins are polyphenolic, plant secondary metabolites, which are widely known for antioxidant properties. Catechins derive their name from catechu, a plant extract of Acacia catechu, from which it was first isolated. Catechins are grouped under flavan-3-ols, a class of flavonoids that also include catechin gallates, the gallic esters of catechins.

\section{Structure}

The catechins and catechin gallates use 2-phenyl-3,4-dihydro$2 \mathrm{H}$ chromen-3-ol skeleton in their chemical structure. Catechins normally possess three rings (two benzene and a dihydropyran heterocycle) with two chiral centres. This gives two trans- and two cis- isomers, called catechins and epicatechins respectively. The benzene rings (called A and B rings) are similar to resorcinol and catechol moieties respectively. The $\mathrm{B}$ ring catechol moiety and the hydroxyl group (on ring $\mathrm{C}$ of ungallolyated catechins or on rings $\mathrm{B}$ and D in gallolyated catechins) are important for their antioxidant properties (Tournaire et al., 1993; Salah et al., 1995). The 
<smiles>Oc1cc(O)c2c(c1)OC(c1ccc(O)c(O)c1)C(O)C2</smiles>

Epicatechin<smiles>Oc1cc(O)c2c(c1)OC(c1cc(O)c(O)c(O)c1)C(O)C2</smiles>

\section{Epigallocatechin}<smiles>O=C(OC1Cc2c(O)cc(O)cc2OC1c1ccc(O)c(O)c1)c1cc(O)c(O)c(O)c1</smiles>

Epicatechin Gallate<smiles>O=C(OC1Cc2c(O)cc(O)cc2OC1c1cc(O)c(O)c(O)c1)c1cc(O)c(O)c(O)c1</smiles>

Epigallocatechin gallate

prevents oxidation of biomolecules by ROS (Maurya and Rizvi, 2009; Raza and John, 2007). The exact mechanism of action of catechins is yet to be shown in vivo, though several in-vitro and in-vivo studies have been carried out in animal and human models. Concentration dependent inhibition of NAPDPH/Fe2+ induced lipid peroxidation in rat microsomes and the inhibition of CYP2E1 activity, involved in ROS production and metabolism have been reported (Choi et al., 2002; Raza and John, 2007). Catechins have been reported to possess anti-inflammatory activities by which they prevent a chronic state of inflammation. They may achieve this by inhibition of COX-1/COX-2 enzymes

Fig.1. Diagrams of tea catechins.

(Seeram et al., 2003;

importance of the gallate group of the C-3 position has been reported (Sanae et al., 2002).

\section{Sources}

Catechins are widely found in tea from Camellia sinensis, cocoas, chocolates, fruits, vegetables, and wines (Hammerstone et al., 2000; Ruidavets et al., 2000; Zaveri, 2006). Catechins contribute $30-40 \%$ of the dry weight of a green tea extract (GTE). Thus, green tea beverages are an excellent source of these polyphenols (Wang et al., 1994; Raza and John, 2007). The catechin content has been reported to be four times more in chocolates than in tea (Arts et al., 1999), while apricots containing $250 \mathrm{mg} / \mathrm{kg}$ fresh weight are the richest source (Manach et al., 2004).

\section{Production of tea plant}

The tea plant (Camellia sinensis) belongs to Theaceae family. It is originated in China, Tibet and Northern India. There are about 200 species of tea plant. It is cultivated in tropical and temperate places and with average yearly rain fall of $2000 \mathrm{~mm}$. Tea comes from the leaves and buds of tea plants. There are mainly three types of tea: black tea, white tea and green tea. The difference in different types of tea is the mode of production. An important phase in the production process is the stage in which leaves are dried. This stage reduces the moisture and thereby strengthening and preserving the tea leafs. Green tea production process involve: a) Drying: leaves are sundried on bamboo trays for a few hours. Leaves are further roasted in order to vaporize additional moisture. b) Rolling: The leaves are then rolled. c) Drying: The leaves are put back into pans for additional drying. This step is to give them final shape.

\section{Mode of action}

Catechins are known mainly for their antioxidant properties which are primarily due to the ability to scavenge the free radical species and prevent oxidative damage that may otherwise cause toxicity and disorders. The possible mechanisms of scavenging the free radicals have been reviewed earlier by Sutherland (Sutherland et al., 2006) and will not be discussed here. They are known to prevent lipid peroxidation by the initiators of oxidative stress which in turn
Santangelo et al., 2007), repression of nitric oxide (NO) production (Lyu and Park, 2005; Santangelo et al., 2007), varying degrees of regulation of the expression of proinflammatory cytokines like IL-6 and IL-12 (Ichikawa et al., 2004; Santangelo et al., 2007) or by the inhibition of nuclear

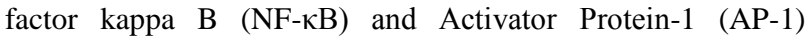
mediated gene activation (Ichikawa et al., 2004; Ahmad et al., 2000; Zaveri, 2006). Catechins inhibit the activation of genes in response to ROS; for example, in the case of NF- $\mathrm{\kappa B}$ by either scavenging ROS or by reducing the degradation of the I $\kappa \mathrm{B}$, the inhibitory protein for NF- $\mathrm{KB}$ (Nam et al., 2001; Ichikawa et al., 2004; Zaveri, 2006). As chronic inflammation occurs only when the normal inflammatory response of the body is disturbed, it may be a common link between chronic disorders. Thus, the role of catechins and other polyphenols as antiinflammatory molecules is an important property against ROS and oxidative stress.

\section{Aging}

Among several theories that attempt to explain the process of aging, oxidative stress hypothesis offers the best mechanistic elucidation of aging and other related phenomena (Janqueira et al., 2004). According to the free radical theory (Harman, 1994), an increase in generation of free radicals and oxidative stress is responsible for age related deterioration and disorders. Though small amounts of oxidative damage keep occurring even normally, the rate of this damage increases with the aging process, with the decline in antioxidative (Andriollo-Sanchez et al., 2005) and repair mechanisms (Inal et al.,2001). In several studies, oxidative damage as a function of age has been reported. In recent studies, we took erythrocytes as a model to demonstrate age associated changes in biomarkers of oxidative stress viz. malondialdehyde (MDA), reduced glutathione and membrane- SH groups (Rizvi and Maurya, 2007), NO (Maurya and Rizvi, 2009), superoxide dismutase (SOD)and catalase (Rizvi and Maurya, 2007), glutathione-S-transferase (GST) (Maurya and Rizvi, 2010), glutathione peroxidise activity (GPx) (Maurya et al.,2010), and a significant age dependent decline in plasma antioxidant capacity, measured in terms of ferric reducing ability of plasma (FRAP) values (Rizvi et al.,2006). A similar study on European subjects showed a highly significant 
correlation between sensitivity and early markers of oxidative stress and aging (Andriollo-Sanchez et al., 2005). A significant correlation between the decline in total antioxidant capacity of plasma and age associated increase in protein carbonyls (PCO), advanced oxidation protein products (AOPPs) and loss in plasma thiol groups (T-SH) content in Indian population was demonstrated (Pandey et al., 2010). A similar age related increase in the carbonyl content of proteins in RBCs (Oliver et al., 1987), the human brain (Smith et al., 1991) and rat hepatocytes (Starke-Reed and Oliver, 1989) have been reported (Berlett and Stadtman, 1997). The correlation between antioxidant capacity and oxidative damage has been reported in several tissues of humans and different animal species (Inal et al., 2001; Melov, 2002).

The role of dietary antioxidants in aging and age related diseases always finds importance (Maurya et. al., 2009; Rizvi and Maurya, 2008; Rizvi et. al., 2009). Recently we reported the role of tea catechins in aging and other age related diseases (Maurya and Prakash, 2011; Kumar et al., 2010). Tea catechins have been shown to protect erythrocytes from oxidative stress induced by tert-butyl hydroperoxide (t-BHP) by decreasing MDA levels and preventing oxidation of membrane -SH groups. The study demonstrated EGCG as most effective in protection of RBCs in both the cases (Maurya and Rizvi, 2008). Also, green tea has been shown to protect against ethanol induced oxidative stress and aging in the blood serum of mice (Luczaj et al., 2004). Another set of studies showing the concentrationdependent effect of tea catechins, demonstrate, at lower concentrations they reduce MDA formation, displaying antioxidant properties, while at higher concentrations they induce oxidative stress (Raza and John, 2007; Zhou, 2004). While GPx activity decreases with age in a significant correlation with the total antioxidant capacity of plasma (Maurya et al., 2010), a study on a hepatocyte cell line in rats indicates an increase in GPx activity in Se (+) cells with the addition of catechins in media (Nagata et al., 1999). This data clearly suggests a direct correlation between oxidative stress and aging and usefulness of tea catechins in protection against it. The possible mechanisms of action of catechins have been mentioned in section 2, though the exact mechanisms remain speculative. Tea catechins have been studied for their effects on various age associated disorders like neurodegenerative disorders, cancer and cardiovascular diseases, and in the next section we will review such studies.

\section{Neurodegenerative disorders}

Several age-associated deficits in motor and cognition activities of brain are reported, with their occurrence both in the presence and absence of chronic disorders like Alzheimer's disease (AD) and Parkinson's disease (PKD) (Kluger et al., 1997; Joseph et al., 1983; West, 1996; Youdim and Joseph, 2001). The human brain, especially its hippocampus, dorsomedial striatum and prefrontal cortex, plays an important role in spatial learning, memory and cognition (McDonald and White, 1994; Devan et al., 1996). It has been suggested that the age-associated deficit in cognitive function is associated with a decline in neurotransmitter sensitivity (Shukitt-Hale et al, 1998), while the motor function deficit has been related to an altered dopamine system or cerebellum (Bickford et al., 1992; Bickford, 1993; Shukitt-Hale et al., 2008). It has been reported that oxidative stress is involved as one of the causes in neurodegenerative disorders like AD and PKD (Gotz et al., 1990; Riederer et al., 1989; Perry et al., 2002) and age associated behaviour deficits (Shukitt-Hale, 1999). Apart from oxidative stress, inflammatory changes and iron accumulation (Gerlach et al., 2003; Youdim et al., 2004) have been suggested and reported to be involved in neurodegenerative diseases. Iron accumulation occurs in specific areas of the brain where degeneration occurs, in both PKD and AD (Riederer et al., 1989). In $\mathrm{AD}$, the free iron pool leads to neocortical amyloid $\beta$ peptide $(\mathrm{A} \beta$ ) deposition, the hyperphosphorylation of tau (PHF$\tau$, a major component of neurofibrillary tangles) and tangle formation (Weinreb et al., 2004).

Tea catechins have long been studied for their neuroprotective abilities and mechanisms (Mandel et al., 2005; Weinreb et al., 2004). The metal chelating ability of catechins, especially in the case of iron (Mandel et al., 2004), is of importance in the cases of $\mathrm{AD}$ and PKD. Owing to this iron chelation ability, it provides neuroprotection against many neurotoxic insults and also helps in the regulation of amyloid precursor proteins (APP) processing both in-vitro and in-vivo (Mandel et al., 2004; Levites et al., 2003; Lim et al., 2001). The catechin activity leads to a decrease in the free iron pool, leading to the suppression of APP mRNA translation (Rogers et al., 2002) and a decrease in $A \beta$ aggregation (Ono et al., 2003) which otherwise promotes oxidative stress. It also increases production of the soluble form of APP ( $\mathrm{AAPP} \alpha)$ (Levites et al., 2003), a neuroprotectant (Mattson et al., 1997), via PKC dependent activation of $\alpha$-secretase that promotes solubilisation of PHF $\tau$ in AD brains (Yamamoto et al., 2002; Mandel et al., 2005; Ramassamy, 2006). In a study by $\mathrm{Li}$ and co (Li et al., 2009), the Morris Water Maze method was used to evaluate the spatial learning and memory deficits and study the effects of GTC on them. This study on C57BL/6 mice involved 6 month pre-feeding with GTC in water, and demonstrated that $0.5 \%$ and $0.1 \%$ GTC in water prevented age related spatial learning and memory decline. In the same study, GTC was shown to increase CREB activation after MWM activity which can rescue aged animals from deficits in a special memory. Further in this study, the age dependent decrease in PSD95 and CaMKII proteins and corresponding increase in these proteins by GTC were shown. In other similar studies, Hindmarch et al. (2000) have also reported improved cognitive and psychomotor performances in adults with tea consumption. Improvement in deficits induced by cerebral ischemia, with help of tea catechins and epicatechins, has also been reported in various studies (Matsuoka et al., 1995). Also, nutritional studies have shown that tea consumption has a role in neurodegenerative disorders like PKD (Checkoway et al., 2002). The Catechol like structure has been attributed to a neuroprtotective ability as it may competitively inhibit 1-methyl-4-phenylpyridinium $\left(\mathrm{MPP}^{+}\right)$intake which prevents MPTP/MPP ${ }^{+}$induced damage (Pan et al., 2003). EGCG decreases bax expression, a proapoptotic gene (Levites et al., 2002; Mandel et al., 2004), responsible for the decrease in membrane potential in mitochondria by opening the mitochondrial mega-channel permeability transition pore (mPTP) which leads to cytochrome c release and cell death (Cory and Adams, 2002; Bernardi et al., 2001).This way, by maintaining mitochondrial integrity in nonrenewable cells like neurons, contributes to neuroprotection (Mandel et al., 2005). Studies have also reported that EGCG increases SOD and catalase activity in the striatum of rats (Levites et al., 2001) and preserves striatal dopamine levels (Choi et al., 2002). Overall, ECG and EGCG have been shown to possess more validity in cases of neurodegenerative diseases as compared to other catechins owing to their capacity to cross blood brain barriers (Suganuma et al., 1998).

\section{Cancer}

Age is one of the factors that strongly determine the probability of curable cancer (Carter et al, 1999). The effect of tea catechins has long been studied for cancers affecting the oesophagus (Gao et al., 1994), stomach (Hibasami et al., 1998), duodenum (Yamane et al., 1996), colon and rectum (Ji et al., 
1997; Jung et al., 2001), breast and mammary glands (Liao et al., 1995; Hirose et al., 1995), lungs (Zhong et al., 2001), pancreas (Bt et al., 1997), bladder (Wakai et al., 1993), prostrate (Jain et al., 1998, Paschka et al.,1998), skin (Wang et al, 1989) and blood (Hayakawa et al., 2001). Effects of catechins in cancer prevention has been suggested through several factors viz. the decrease or lowering of lipid hyperoxidation (Matsumoto et al., 1996), DNA damage (Inagake et al., 1995), and very low density lipoproteins (VLDL) and low density lipoproteins (LDL) cholesterol (Zhang et al., 2002). They also reduce the number, weight and volume of tumours (Zhu et al.,1999; Xu et al., 1992; Cao et al., 1996), suggesting their role in the reduction of cancer effects. In a study on Japanese patients, green tea has been reported to lower the recurrence of stage I and II breast cancer $(p<0.05)$ on increased consumption (Nakachi et al., 1998). While another study on Japanese patients found no significant inverse relation between green tea consumption and the risk of stomach cancer (Hoshiyama et al., 2004). Wang (Wang et al., 1989) suggested green tea polyphenols have a significant anti-skin tumour initiating activity when tested against polycyclic aromatic hydrocarbons in mice. Catechins possess antimutagenic activities (Bu-Abbas et al., 1994), and anti-genotoxic effects (Sugisawa et al., 2004), induce apoptosis in cancer cells (Hayakawa et al., 2001), and inhibit angiogenesis (Jung et al., 2001) that makes them useful as anti-carcinogenic compounds. In epithelial tumours, the epidermal growth factor receptor (EGFR) is highly expressed and is inhibited by EGCG (Masuda et al., 2001; Shimizu et al., 2005). Jung (Jung et al., 2001), suggested the inhibition of tumour growth in human colon carcinoma cells. In their study, they examined the effect of EGCG on transcriptional regulation of vascular endothelial growth factor (VEGF), and reported a dose dependent inhibition of VEGF promoter activity. Also, they reported a $30 \%$ (compared to controls) decrease in vessel formation in tumour regions using immunohistochemical staining. In a placebo controlled study, Bettuzzi (Bettuzzi et al., 2006) suggested $90 \%$ chemoprevention efficacy for human prostate cancer $(\mathrm{CaP})$, after conducting a proof-of-principle clinical trial for which 60 patients with high grade PIN (HGPIN), the main premalignant lesion of $\mathrm{CaP}$, were selected.

Sugisawa et al. (2004) investigated the effects of tea catechins on chromosomal damage by cytokinesis-block assay, and reported preventive effects against ROS-induced chromosomal damage. EGCG has been shown to cause DNA fragmentation and initiating apoptosis in small-cell lung carcinoma (SCLC) (Sadava et al., 2007). EGCG has also been reported to possess the ability to inhibit the telomerase enzyme (Mittal et al., 2004). Telomerase is known to be an important enzyme that maintains telomere length in cancer cells and thus keeps such cells proliferative (Kim et al., 1994; Shay et al., 2001). It has been suggested that EGCG can cause cancer cell death by antioxidant and epigenetic modulation and has been reported to inhibit human telomerase reverse transcriptase (hTRT) (Berletch et al., 2008), which is an essential catalytic component of telomerase. As telomere shortening is thought to control cellular aging (Morales et al., 1999; Shay et al., 2001), it suggests further evidence of a correlation between aging and cancer. Hakim and co-workers (Hakim et al., 2003) demonstrated a decrease in 8-hydroxy-2'-deoxyguanosine (8OHdG), a marker of oxidative stress, in former smokers after the consumption of four cups of green tea. This supports its antioxidative nature to be helpful in cancer prevention. The antioxidative and pro-oxidant effects of catechins have widely been reported in both human and animal models in support of cancer prevention (Lambert and Elias, 2010; Kuroda and Hara, 1999).

\section{Cardiovascular diseases}

Cardiovascular diseases are long known to be age associated disorders. The risk of incidence of cardiovascular disease increases with advancing age, and this primarily occurs due to aging structure and function of the cardiovascular system (Lakatta and Levy, 2003). Wall thickening and dilatation of large elastic arteries (Lakatta, 1993), intimal thickening of the aortic wall (Virmani et al., 1991) and thickening of the intimal media of the carotid wall (Nagai et al., 1998) with age have earlier been reported (Lakatta and levy, 2003). Also, cardiac hypertrophy and increased accumulation of collagen and fibronectin with aging has been suggested (Burgess et al., 2001). Several other studies have suggested changes in cardiac muscles with increasing age. Mohan and Radha (Mohan and Radha, 1978) in their study on the red, white and cardiac muscles of albino rats, showed an increase in autolysis and $\mathrm{Ca}^{2+}$ activated proteolytic activity of sarcoplasmic proteins with age. Lin (Lin et al., 2008) suggested a decrease in myocytes, increase in myocyte hypertrophy and reparative fibrosis as factors that together depress left ventricular (LV) function and indicate cardiac sarcopenia, which may contribute to responses to problems in elders. In this study, a decrease in glycogen stores in myocardium has been suggested with aging leading to LV dysfunction. Also, ventricular muscle fibres' RNA content has been suggested to decrease with chronological age in the past (Wulff and Freshman, 1961).

As already discussed in the above sections, OS causes deleterious effects mediated by pathogenic overproduction of ROS that overpowers our antioxidant systems and causes aging. ROS have been reported to cause such damage to vascular and cardiac muscles and has been shown to participate in causing atherosclerosis, ischemic heart diseases, hypertension and cardiac hypertrophy (Dhalla et al., 2000). The effects of tea catechins, especially EGCG, have been investigated and widely suggested in epidemiological, experimental and clinical studies (Velayutham et al., 2008). Many mechanisms have been indicated in such studies, viz. antioxidative, anti-proliferative, anti-inflammatory, anti-platelet and anti-thrombotic activities, and the ability to affect lipid metabolism and vascular homeostasis (Velayutham et al., 2008). Miura (Miura et al., 2000), demonstrated green tea polyphenols increased $\alpha$ tocopherol and $\beta$ carotene concentration, which are endogenous antioxidants in LDL. In oxidation mediated by ROS, LDL loses these endogenous lipophilic antioxidants (Esterbauer et al., 1987). In their study (Miura et al., 2000) they showed a prolonged lag time (14 min) of LDL oxidation in a group that consumed tea and thus suggested green tea to be capable of rendering LDL resistant to in-vivo oxidative damage and thus reducing the rate of cardiovascular diseases. Son (Son et al., 2004) reported the inhibition of rabbit platelet aggregation induced by collagens, arachidonic acid (AA), etc in-vitro and ex-vivo, by GTC. Also in their study, ATP release from dense granules in the platelet was shown to be inhibited by GTC, which otherwise are involved in platelet activation. This investigation (Son et al., 2004) also inferred that GTC used the COX pathway for their anti-platelet activity, by which they prevent platelet aggregation and thus avoid arterial thrombi that cause thromboembolic problems atherosclerosis and other cardiovascular diseases (Packham, 1994). Song et al. (2002) reported the inhibition of age associated Maillard type fluorescence in the aortic collagen of Spague-Dawley rats. These Maillard-type fluorescence causing compounds (Dyer et al., 1993) are part of advanced glycation end products (AGEs) which can cause thrombogenesis upon interaction with vascular cells (Vlassara et al., 1994; Bucala et al., 1991). A study (Sachinidis et al., 2002) reported the anti-proliferative effects of catechins (especially ECG, EGCG and EGC) by which they 
inhibit phosphorylation of a platelet derived growth factor (PDGF-R $\beta$ ) and vascular smooth muscle cell (VSMC) proliferation and thus possess a preventive role in proliferative cardiovascular diseases. A study further supports (Kang et al., 1999) the anti-thrombotic effects of EGCG and GTC, suggesting anti-platelet activities as the reason for such effects. In their study, GTC and EGCG prolonged the tail bleeding time in-vivo (mice) and inhibited platelet aggregation in-vitro (humans).

Nagao et al. (2007) suggested a reduction in body fat, LDL cholesterol and systolic blood pressure on the consumption of GTE rich in catechins, and thus could lower cardiovascular risks and obesity. As obesity and fat accumulation are well correlated to hypertension (Kanai et al., 1990), the above findings may also suggest the prevention of hypertension by catechins. Recently in a study (Kumar et al., 2010), the high intake of catechin rich diet has been suggested in prevention of OS in hypertension. In this study, the strong anti-oxidant ability of EC has been indicated and use of catechins as antihypertensive agents suggested. Catechins may also prevent atherogenesis by inhibiting LDL induced human VSMC proliferation (Locher et al., 2002). The findings of El Bedoui et al. (2005) indicate GTC to potentially inhibit VSMC invasion and thus are able to cause retardation in the development of lesions in atherosclerosis. EGCG also lowers the C-reactive protein (CRP) expression and levels of mRNA transcript for CRP and also prevents atherosclerosis (Ramesh et al., 2010). CRP is a biomarker for inflammation, which is involved in atherosclerosis (Verma and Yeh, 2003) and also causes production of ROS (Wang et al., 2003). Koga and Meydani (Koga and Meydani, 2001) prepared plasma metabolites of (+) catechin via intragstric administration and tested for their effects on monocyte adhesion to human aortic endothelial cells (HAEC). In their study, they found that (+) catechin metabolites inhibited cell adhesion to HAEC and decreased the generation of ROS. In a study by Osada et al. (2001), catechins inhibited cholesterol oxidation and the formation of $7 \beta$ hydroxycholesterol, 53-epoxycholesterols and 7-keto cholesterol with the addition of catechins to LDL, and it is suggested that the radical scavenging action was responsible for it. Stangl et al. (2007) detailedly reviewed on the mechanisms of catechin action in the prevention of cardiovascular diseases. A recent study (Upaganlawar and Balaraman, 2010) reported green tea with vitamin $\mathrm{E}$ reduced OS during myocardial infarction (MI) in rats. Finally, as demonstrated by $\mathrm{Li}$ et al. (2006), EGCG also inhibits upregulated expressions of three major subunits of NAD $(\mathrm{P}) \mathrm{H}$ oxidase that otherwise cause increased ROS production. They reported that EGCG inhibits cardiac hypertrophy via blocking of ERKs, p38, Jun $\mathrm{NH}_{2}$-terminal kinases (JNKs) and IKK $\beta / \mathrm{NF}$ $\kappa \mathrm{B}$ activation and inhibiting $\mathrm{AP}-1$, that otherwise induces cardiac hypertrophy (Sanna et al., 2005). In a recent study, cigarette smoking induced alterations viz. increased LPO and protein carbonyls and decreased enzymatic and non-enzymatic antioxidants were shown to be bettered by EGCG (Gokulakrisnan et al., 2010).

\section{Pharmacokinetics and bioavailability}

Lee et al. (2002) suggested that even after a consumption equivalent to $\sim 2$ cups of tea, plasma EGCG level was $0.17 \mu \mathrm{m}$ which is far lower than that used in cell culture systems in-vitro. In this study, EGCG consumption equivalent to $195 \mathrm{mg}$ (for 70 $\mathrm{kg}$ body weight) i.e. $20 \mathrm{mg}$ tea solids $/ \mathrm{kg}$ were dosed. While Erba (Erba et al., 2005) investigated the effects of two cups of green tea consumption ( $250 \mathrm{mg}$ catechins) and found significant effects on plasma total antioxidant capacity (increased), plasma peroxide levels and LDL cholesterol (decreased) after $48 \mathrm{~h}$ of consumption. In several other pharmacokinetic studies so far, significant bioavailability of EGCG and other tea catechins when compared to concentrations used in-vitro in experiments has not been revealed. This leaves room for many further investigations and trials in this respect. Chow and Hakim (2010) detailedly reviewed on pharmacokinetics and metabolism.

\section{CONCLUSION}

The normal human body has a very complex and efficient antioxidant system consisting of a number of interrelated antioxidant compounds and enzymes. Mechanism(s) that are thought to be involved in the increased oxidative stress as a function of human age include not only oxygen free radical generation but also changes in the tissue/plasma content and the activity of the antioxidant defence system. The present review may have implications in designing the strategies for the use of tea catechins as anti-aging agents in age related diseases. We hypothesise that a high intake of catechin rich diet by higher age groups may provide some protection against the development of age related diseases and slow down the aging process.

\section{CONFLICT OF INTEREST}

The authors have no conflicting financial interests.

\section{REFERENCES}

Ahmad N, Gupta S, Mukhtar H. Green tea polyphenol epigallocatechin-3-gallate differentially modulates nuclear factor kappaB in cancer cells versus normal cells. Arch Biochem Biophys. 2000;376:338-346.

Andriollo-Sanchez M, Hininger-Favier I, Meunier N, Venneria E, O'Connor JM, Maiani G, Coudray C, Roussel AM. Agerelated oxidative stress and antioxidant parameters in middleaged and older European subjects: the ZENITH study. Eur J Clin Nutr. 2005;59:S58-62.

Arts IC, Hollman PC, Kromhout D. Chocolate as a source of tea flavonoids. Lancet. 1999;354:488.

Berletch JB, Liu C, Love WK, Andrews LG, Katiyar SK, Tollefsbol TO. Epigenetic and genetic mechanisms contribute to telomerase inhibition by EGCG. J Cell Biochem. 2008;103:509-519.

Berlett BS, Stadtman ER. Protein Oxidation in Aging, Disease, and Oxidative Stress. J Biol Chem. 1997;272:20313-20316.

Bernardi P, Petronilli V, Di Lisa F, Forte M. A mitochondrial perspective on cell death. Trends Biochem Sci. 2001;26:112117.

Bettuzzi S, Brausi M, Rizzi F, Castagnetti G, Peracchia G, Corti A. Chemoprevention of human prostate cancer by oral administration of green tea catechins in volunteers with HighGrade Prostate Intraepithelial Neoplasia: A preliminary report from a one-year proof-of-principle study. Cancer Res. 2006;66:1234-1240. 
Bickford P, Heron C, Young DA, Gerhardt GA, De La Garza R. Impaired acquisition of novel locomotor tasks in aged and norepinephrine-depleted F344 rats. Neurobiol Aging.1992;13:475-481.

Bickford P. Motor learning deficits in aged rats are correlated with loss of cerebellar noradrenergic function. Brain Res.1993; 620:133-138.

Bu-Abbas A, Clifford MN, Walker R, Ioannides C. Marked antimutagenic potential of aqueous green tea extracts: mechanism of action. Mutagenesis 1994;9:325-331.

Bucala R, Tracey KJ, Cerami A. Advanced glycosylation products quench nitric oxide and mediate defective endothelium-dependent vasodilatation in experimental diabetes. J Clin Invest.1991;87:432-438.

Burgess ML, McCrea JC, Hedrick HL. Age-associated changes in cardiac matrix and integrins. Mech Ageing Dev. 2001;122:1739-1756.

Cao J, Xu Y, Chen J, and Klaunig JE. Chemopreventive effects of green and black tea on pulmonary and hepatic carcinogenesis. Fundam Appl Toxicol. 1996;29:244-250.

Carter HB, Epstein JI, Partin AW. Influence of age and prostate-specific antigen on the chance of curable prostate cancer among men with nonpalpable disease. Urology. 1999;53:126-130.

Checkoway H, Powers K, Smith-Weller T, Franklin GM, Longstreth WT Jr, Swanson PD. Parkinson's disease risks associated with cigarette smoking, alcohol consumption, and caffeine intake. Am J Epidemiol. 2002;155:732-738.

Choi JY, Park CS, Kim DJ, Cho MH, Jin BK, Pie JE, Chung WG. Prevention of nitric oxide-mediated 1-methyl-4-phenyl1,2,3,6-tetrahydropyridine-induced Parkinson's disease in mice by tea phenolic epigallocatechin 3-gallate. Neurotoxicol. 2002;23:367-374.

Chow HH, Hakim IA. Pharmacokinetic and chemoprevention studies on tea in humans. Pharmacol Res. 2011;64:105-112.

Cory S, Adams JM. The Bcl2 family: Regulators of the cellular life-or-death switch. Nat Rev Cancer. 2002;2:647-656.

Devan BD, Goad EH, Petri HL. Dissociation of hippocampal and striatal contributions to spatial navigation in the water maze. Neurobiol Learn Mem. 1996;66:305-323.

Dhalla NS, Temsah RM, Netticadan T. Role of oxidative stress in cardiovascular diseases. J Hypertens. 2000;18:655-673.

Dyer DG, Dunn JA, Thorpe SR, Bailie KE, Lyons TJ, McCance DR, and Baynes JW. Accumulation of Maillard reaction products in skin collagen in diabetes and aging. J Clin Invest. 1993;91:2463-2469.

El Bedoui J, Oak MH, Anglard P, Schini-Kerth VB. Catechins prevent vascular smooth muscle cell invasion by inhibiting MT1-MMP activity and MMP-2 expression. Cardio Res. 2005;67:317-325.

Erba D, Riso P, Bordoni A, Foti P, Biagi PL, Testolin G. Effectiveness of moderate green tea consumption on antioxidative status and plasma lipid profile in humans. J Nutr Biochem. 2005;16:144-149.

Esterbauer H, Jurgens G, Quehenberger O, and Koller E. Autoxidation of human low density lipoprotein: loss of polyunsaturated fatty acids and vitamin $\mathrm{E}$ and generation of aldehydes. J Lipid Res. 1987;28:495-509.

Gao YT, McLaughlin JK, Blot WJ, Ji BT, Dai Q, Fraumeni JF Jr. Reduced risk of esophageal cancer associated with green tea consumption. J Natl Cancer Inst. 1994;86:855-858.

Gerlach M, Double KL, Ben-Shachar D, Zecca L, Youdim MB, Riederer P. Neuromelanin and its interaction with iron as a potential risk factor for dopaminergic neurodegeneration underlying Parkinson's disease. Neurotox Res. 2003;5:35-44.

Gokulakrisnan A, Vinayagam MM, Rahman LAA, Thirunavukkarasu C. Attenuation of cardiac oxidative stress by (-)-epigallocatechin-gallate(EGCG) in CS exposed rats. Biomed Pharmacother. 2010 Oct 23. [Epub ahead of print]

Gotz ME, Freyberger A, Riederer P. Oxidative stress: a role in the pathogenesis of Parkinson's disease. J Neural Transm. 1990;29:241-249.

Graham HN. Green tea composition, consumption, and polyphenol chemistry. Prev Med. 1992;21:334-350.

Gutteridge JM. Free radicals in disease processes: a compilation of cause and consequence. Free Radic Res Commun.1993;19:141-158.

Hakim IA, Harris RB, Brown S, Chow HH, Wiseman S, Agarwal S, Talbot W. Effect of increased tea consumption on oxidative DNA damage among smokers: a randomized controlled study. J Nutr. 2003;133:3303S-3309S.

Halliwell B, Gutteridge JM. Oxygen free radicals and iron in relation to biology and medicine: some problems and concepts. Arch Biochem Biophys. 1986;246:501-514.

Hammerstone JF, Lazarus SA, Schmitz HH. Procyanidin content and variation in some commonly consumed foods. J Nutr. 2000;130:2086S-2092S.

Harman D. Free radical involvement in aging. Pathophysiology and therapeutic implications. Drug Aging. 1993;3:60-80.

Harman D. Free-radical theory of aging. Increasing the functional life span. Ann N Y Acad Sci 1994;717:1-15.

Hayakawa S, Saeki K, Sazuka M, Suzuki Y, Shoji Y, Ohta T, Kaji K, Yuo A and Isemura M. Apoptosis induction by epigallocatechin gallate involves its binding to Fas. Biochem Biophys Res Commun. 2001; 285:1102-1106.

Hibasami H, Komiya T, Achiwa Y, Ohnishi K, Kojima T, Nakanishi K, Akashi K, Hara Y. Induction of apoptosis in human stomach cancer cells by green tea catechins. Oncol Rep.1998;5:527-529.

Hindmarch I, Rigney U, Stanley N, Quinlan P, Rycroft J, Lane $\mathrm{J}$ : A naturalistic investigation of the effects of day-long consumption of tea, coffee and water on alertness, sleep onset and sleep quality. Psychopharmacol. 2000;149:203-216. 
Hirose M, Akagi K, Hasegawa R, Yaono RM, Satoh T, Hara Y, Wakabayashi K, Ito N. Chemoprevention of 2-amino-1-methyl6-phenylimidazow[4,5-b]-pyridine (PhIP).-induced mammary gland carcinogenesis by antioxidants in F344 female rats. Carcinogenesis. 1995;16:217-221.

Hoshiyama Y, Kawaguchi T, Miura Y, Mizoue T, Tokui N, Yatsuya H, Sakata K, Kondo T, Kikuchi S, Toyoshima H, Hayakawa N, Tamakoshi A, Ohno Y, Yoshimura T; Japan Collaborative Cohort Study Group. A nested case-control study of stomach cancer in relation to green tea consumption in Japan. Br J Cancer. 2004;90:135-138.

Ichikawa D, Matsui A, Imai M, Sonoda Y, Kasahara T. Effect of various catechins on the IL-12p40 production by murine peritoneal macrophages and a macrophage cell line, J774.1. Biol Pharm Bull. 2004;27:1353-1358.

Inagake M, Yamane T, Kitao Y, Oya K, Matsumoto $\mathrm{H}$, Kikuoka N, Nakatani H, Takahashi T, Nishimura H, Iwashima A. Inhibition of 1,2-dimethylhydrazine-induced oxidative DNA damage by green tea extract in rat. Jpn $\mathrm{J}$ Cancer Res.1995;86:1106-1111.

Inal ME, Kanbak G, Sunal E. Antioxidant enzyme activities and malondialdehyde levels related to aging. Clin Chim Acta. 2001;305:75-80.

Jain M, Hislop G, Howe G, Burch J, Ghadirian P. Alcohol and other beverage use and prostate cancer risk among Canadian men. Int J Cancer.1998;78:707-711.

Janqueira VB, Barros SB, Chan SS, Rodriguez I, Giavarotti L, Abud RL, Deucher GP. Aging and oxidative stress. Mol Aspects Med. 2004;25:5-16.

Ji BT, Chow WH, Hsing AW, McLaughlin JK, Dai Q, Gao YT, Blot WJ, Fraumeni JF Jr. Green tea consumption and the risk of pancreatic and colorectal cancers. Int J Cancer. 1997;70:255258.

Joseph JA, Bartus RT, Clody DE, Morgan D, Finch C, Beer B, Sesack S. Psychomotor performance in the senescent rodent: reduction of deficits via striatal dopamine receptor upregulation. Neurobiol. Aging. 1983;4:313-319.

Jung YD, Kim MS, Shin BA, Chay KO, Ahn BW, Liu W, Bucana CD, Gallick GE and Ellis LM. EGCG, a major component of green tea, inhibits tumour growth by inhibiting VEGF induction in human colon carcinoma cells. Br J Cancer. 2001;84:844-850.

Kanai H, Matsuzawa Y, Kotani K, Keno Y, Kobatake T, Nagai Y, Fujioka S, Tokunaga $\mathrm{K}$ and Tarui S. Close correlation of intra-abdominal fat accumulation to hypertension in obese women. Hypertension. 1990;16:484-490.

Kang WS, Lim IH, Yuk DY, Chung KH, Park JB, Yoo HS, Yun YP. Antithrombotic Activities of Green Tea Catechins and (-)-Epigallocatechin Gallate. Thromb Res. 1999;96:229-237.

Kim NW, Piatyszek MA, Prowse KR, Harley CB, West MD, Ho PL, Coviello GM, Wright WE, Weinrich SL and Shay JW. Specific association of human telomerase activity with immortal cells and cancer. Science. 1994;266:2011-2115.
Kluger A, Gianutsos JG, Golomb J, Ferris SH, George AE, Frannssen E, Reisberg B. Patterns of motor impairment in normal aging, mild cognitive decline, and early Alzheimer's disease. J Gerontol B Psychol Sci Soc Sci.1997;52:28-39.

Koga T, Meydani M. Effect of plasma metabolites of (+)catechin and quercetin on monocyte adhesion to human aortic endothelial cells. Am J Clin Nutr. 2001;73:941-948.

Kumar N, Kant R, Maurya PK. Concentration-dependent effect of (-) epicatechin in hypertensive patients Phytother Res. 2010; 24:1433-1436.

Kuroda Y, Hara Y. Antimutagenic and anticarcinogenic activity of tea polyphenols. Mutat Res. 1999;436:69-97.

Lakatta EG, Levy D. Arterial and cardiac aging: Major shareholders in cardiovascular disease enterprises: Part I: Aging arteries: A "set up" for vascular disease. Circulation. 2003;107:139-146.

Lakatta EG. Cardiovascular regulatory mechanisms in advanced age. Physiol Rev.1993;73:413-467.

Lambert JD, Elias RJ. The antioxidant and pro-oxidant activities of green tea polyphenols: A role in cancer prevention. Arch Biochem Biophys. 2010;501:65-72.

Lee MJ, Maliakal P, Chen L, Meng X, Bondoc FY, Prabhu S, Lambert G, Mohr S, Yang CS. Pharmacokinetics of tea catechins after ingestion of green tea and (-)-epigallocatechin3 -gallate by humans : Formation of different metabolites and individual variability. Cancer Epidemiol Biomarkers Prev. 2002;11:1025-1032.

Levites Y, Amit T, Mandel S, Youdim MB. Neuroprotection and neurorescue against amyloid beta toxicity and PKCdependent release of non-amyloidogenic soluble precursor protein by green tea polyphenol (-)epigallocatechin-3gallate.FASEB J. 2003;17:952-954.

Levites Y, Amit T, Youdim MB, Mandel S. Involvement of protein kinase $\mathrm{C}$ activation and cell survival/cell cycle genes in green tea polyphenol (-)-epigallocatechin-3-gallate neuroprotective action. J Biol Chem. 2002;277:30574-30580.

Levites Y, Weinreb O, Maor G, Youdim MB, Mandel S: Green tea polyphenol (-)-epigallocatechin-3-gallate prevents $\mathrm{N}$ methyl-4-phenyl-1,2,3,6-tetrahydropyridine-induced dopaminergic neurodegeneration. J Neurochem. 2001;78(5):1073-1082.

Li HL, Huang Y, Zhang C-N, Liu G, Wei YS, Wang AB, Liu YQ, Hui RT, Wei C, Williams GM, Liu DP, Liang CC. Epigallocathechin-3 gallate inhibits cardiac hypertrophy through blocking reactive oxidative species-dependent and independent signal pathways. Free Radic Biol Med. 2006;40:1756-1775.

Li Q, Zhao HF, Zhang ZF, Liu ZG, Pei XR, Wang JB, Cai MY, $\mathrm{Li}$ Y. Long-term administration of green tea catechins prevents age-related spatial learning and memory decline in C57BL/6 J mice by regulating hippocampal cyclic amp-response element binding protein signaling cascade. Neuroscience. 2009; 159:1208-1215. 
Liao S, Umekita Y, Guo J, Kokontis JM, Hiipakka RA. Growth inhibition and regression of human prostate and breast tumors in athymic mice by tea epigallocatechin gallate. Cancer Lett. 1995;96:239-243.

Lim GP, Chu T, Yang F, Beech W, Frautschy SA, Cole GM. The curry spice curcumin reduces oxidative damage and amyloid pathology in an Alzheimer transgenic mouse. J Neurosci. 2001;21:8370-8377.

Lin J, Lopez EF, Jin Y, Remmen HV, Bauch T, Han HC, Lindsey ML. Age-related cardiac muscle sarcopenia: Combining experimental and mathematical modeling to identify mechanisms. Exp Gerontol. 2008;43:296-306.

Locher R, Emmanuele L, Suter PM, Vetter W, Barton M. Green tea polyphenols inhibit human vascular smooth muscle cell proliferation stimulated by native low-density lipoprotein. Eur J Pharmacol. 2002;434:1-7.

Luczaj W, Waszkiewicz E, Skrzydlewska E, RoszkowskaJakimiec W. Green tea protection against age-dependent ethanol-induced oxidative stress. J Toxicol Environ Health A. 2004;67:595-606.

Lyu SY, Park WB. Production of cytokine and NO by RAW 264.7 macrophages and PBMC in vitro incubation with flavonoids. Arc Pharm Res. 2005;28:573-581.

Manach C, Scalbert A, Morand C, Rémésy C, Jime'nez L. Polyphenols: food sources and bioavailability. Am J Clin Nutr. 2004;79:727-747.

Mandel S, Maor G, Youdim MB: Iron and alpha-synuclein in the substantia Nigra of MPTP-treated mice: Effect of neuroprotective drugs R-apomorphine and green tea polyphenol (-)-epigallocatechin-3-gallate. J Mol Neurosci. 2004;24:401-416.

Mandel SA, Avramovich-Tirosh Y, Reznichenko L, Zheng H, Weinreb O, Amit T, Youdim MB. Multifunctional Activities of Green Tea Catechins in Neuroprotection-Modulation of Cell Survival Genes, Iron-Dependent Oxidative Stress and PKC Signaling Pathway. Neurosignals. 2005;14:46-60.

Maridonneau I, Braquet P, Garay RP. $\mathrm{Na}^{+}$and $\mathrm{K}^{+}$transport damage induced by oxygen free radicals in human red cell membranes. J Biol Chem. 1983;25:3107-31013.

Masuda M, Suzui M, Weinstein IB. Effects of epigallocatechin3 -gallate on growth, epidermal growth factor receptor signaling pathways, gene expression, and chemosensitivity in human head and neck squamous cell carcinoma cell lines. Clin Cancer Res. 2001;7:4220-4229.

Matsumoto H, Yamane T, Inagake M, Nakatani H, Iwata Y, Takahashi T, Nishimura $H$, Nishino $H$, Nakagawa $K$, Miyazawa T. Inhibition of mucosal lipid hyperoxidation by green tea extract in 1,2-dimethylhydrazine-induced rat colonic carcinogenesis. Cancer Lett.1996;104:205-209.

Matsuoka Y, Hasegawa H, Okuda S, Muraki T, Uruno T, Kubota K. Ameliorative effects of tea catechins on active oxygen-related nerve cell injuries. J Pharmacol Exp Ther.1995; 274:602-608
Mattson MP, Barger SW, Furukawa K, Bruce AJ, Wyss-Coray T, Mark RJ, Mucke L. Cellular signaling roles of TGF beta, TNF alpha and beta APP in brain injury responses and Alzheimer's disease. Brain Res Rev. 1997;23:47-61.

Maurya PK, Arora K, Sarkar S. Role of L-ascorbic acid in the stability of human erythrocytes during aging in humans. Indian J Gerontol. 2009;23:1-9.

Maurya PK, Kumar P, Siddiqui N, Tripathi P, Rizvi SI. Ageassociated changes in erythrocyte glutathione peroxidase activity: correlation with total antioxidant potential. Indian J Biochem Biophys. 2010;47:319-321.

Maurya PK, Prakash S. Intracellular uptake of (-) epicatechin by human erythrocytes as a function of human age. Phytotherapy Res. 2011;25:944-46.

Maurya PK, Rizvi SI. Age dependent changes in glutathione-Stransferase: correlation with total total antioxidant potential and red cell intracellular glutathione. Indian J Clin Biochem. 2010;25:398-400.

Maurya PK, Rizvi SI. Alterations in plasma nitric oxide during aging in humans. Indian J Biochem Biophys. 2009;46:130-132.

Maurya PK, Rizvi SI. Protective role of tea catechins on erythrocytes subjected to oxidative stress during human aging. Nat Prod Res. 2009;23:1072-1079.

McDonald RJ, White NM. Parallel information processing in the water maze: evidence for independent memory systems involving dorsal striatum and hippocampus. Behav Neural Biol. 1994;61:260-270.

Melov S. Animal models of oxidative stress, aging and therapeutic antioxidant interventions. Int J Biochem Cell Biol. 2002;34:1395-1400.

Mittal A, Pate MS, Wylie RC, Tollefsbol TO, Katiyar SK. EGCG down-regulates telomerase in human breast carcinoma MCF-7 cells, leading to suppression of cell viability and induction of apoptosis. Int J Oncol. 2004;24:703-710.

Miura Y, Chiba T, Miura S, Tomita I, Umegaki K, Ikeda M, Tomita T. Green tea polyphenols (flavan 3-ols) prevent oxidative modification of low density lipoproteins: An ex vivo study in humans. J Nutr Biochem. 2000;11:216-222.

Mohan S, Radha E. Age related changes in muscle protein degradation. Mech Ageing Dev. 1978;7:81-87.

Morales CP, Holt SE, Ouellette M, Kaur KJ, Yan Y, Wilson KS, White MA, Wright WE, Shay JW. Absence of cancerassociated changes in human fibroblasts immortalized with telomerase. Nat Genet.1999;21:115-118.

Nagao T, Hase T, Tokimitsu I. A green tea extract high in catechins reduces body fat and cardiovascular risks in humans. Obesity. 2007;15:1473-1483.

Nagata H, Takekoshi S, Takagi T, Honma T, Watanabe K. Antioxidative action of flavonoids, quercetin and catechin, mediated by the activation of glutathione peroxidase. Tokai $\mathrm{J}$ Exp Clin Med.1999;24:1-11. 
Nakachi K, Suemasu K, Suga K, Takeo T, Imai K, Higashi Y. Influence of Drinking Green Tea on Breast Cancer Malignancy among Japanese Patients. Jpn J Cancer Res. 1998;89:254-261.

Nam S, Smith DM, Dou QP. Ester bond-containing tea polyphenols potently inhibit proteasome activity in vitro and in vivo. J Biol Chem. 2001;276:13322-13330.

Oliver CN, Ahn BW, Moerman EJ, Goldstein S, Stadtman ER. Age-related changes in oxidized proteins. J Biol Chem. 1987;262:5488-5491.

Ono K, Yoshiike Y, Takashima A, Hasegawa K, Naiki H, Yamada M. Potent anti-amyloidogenic and fibril-destabilizing effects of polyphenols in vitro: Implications for the prevention and therapeutics of Alzheimer's disease. J Neurochem. 2003;87:172-181.

Osada K, Takahashi M, Hoshina S, Nakamura M, Nakamura S, Sugano M. Tea catechins inhibit cholesterol oxidation accompanying oxidation of low density lipoprotein in vitro. Comp Biochem Physiol C Toxicol Pharmacol. 2001;128:153164.

Packham MA. Role of platelets in thrombosis and hemostasis. Can J Physiol Pharmacol. 1994;72:278-284.

Pan T, Fei J, Zhou X, Jankovic J, Le W. Effects of green tea polyphenols on dopamine uptake and on MPP+-induced dopamine neuron injury. Life Sci. 2003;72:1073-1083.

Pandey KB, Mehdi MM, Maurya PK, Rizvi SI. Plasma protein oxidation and its correlation with antioxidant potential during human aging. Dis Markers. 2010;29:31-36.

Paschka AG, Butler R, Young CY. Induction of apoptosis in prostate cancer cell lines by the green tea component, (-)epigallocatechin-3-gallate. Cancer Lett.1998;130:1-7.

Perry G, Taddeo MA, Nunomura A, Zhu X, Zenteno-Savin T, Drew KL, Shimohama S, Avila J, Castellani RJ, Smith MA. Comparative biology and pathology of oxidative stress in Alzheimer and other neurodegenerative diseases: beyond damage and response. Comp Biochem Physiol C Toxicol Pharmacol. 2002;133(4):507-513.

Ramassamy C. Emerging role of polyphenolic compounds in the treatment of neurodegenerative diseases:A review of their intracellular targets. Eur J Pharmacol. 2006;545:51-64.

Ramesh E, Geraldine P, Thomas PA. Regulatory effect of epigallocatechin gallate on the expression of C-reactive protein and other inflammatory markers in an experimental model of atherosclerosis. Chem Biol Interact. 2010;183:125-132.

Raza H, John A. In vitro protection of reactive oxygen speciesinduced degradation of lipids, proteins and 2-deoxyribose by tea catechins. Food Chem Toxicol. 2007;45:1814-1820.

Reiter RJ, Guerrero JM, Garcia JJ, Acuna-Castroviejo D. Reactive oxygen intermediates, molecular damage, and aging. Relation to melatonin. Ann N Y Acad Sci. 1998;854:410-424.

Riederer P, Sofic E, Rausch WD, Schmidt B, Reynolds GP, Jellinger K, Youdim MBH. Transition metals, ferritin, glutathione, and ascorbic acid in parkinsonian brains. J Neurochem. 1989;52:515-520.
Rizvi SI, Maurya PK. Markers of oxidative stress in erythrocytes during aging in humans. Ann N Y Acad Sci. 2007;1100:373-382.

Rizvi SI, Jha R, Maurya PK. Erythrocyte plasma membrane redox system in human aging. Rejuvenation Res. 2006;9:490494.

Rizvi SI, Maurya PK. Alterations in antioxidant enzymes during aging in humans. Mol Biotechnol. 2007;27:58-61.

Rizvi SI, Maurya PK. L-cysteine influx in erythrocytes as a function of human age. Rejuvenation Res. 2008;11:661-665.

Rizvi SI, Pandey KB, Jha R, Maurya PK. Ascorbate recycling by erythrocytes during aging in humans. Rejuvenation Res. 2009;12:3-6.

Rogers JT, Randall JD, Cahill CM, Eder PS, Huang X, Gunshin H, Leiter L, McPhee J, Sarang SS, Utsuki T, Greig NH, Lahiri DK, Tanzi RE, Bush AI, Giordano T. An iron-responsive element type II in the 5'-untranslated region of the Alzheimer's amyloid precursor protein transcript. J Biol Chem. 2002;277:45518-45528.

Ruidavets J, Teissedre P, Ferrières J, Carando S, Bougard G, Cabanis J. Catechin in the Mediterranean diet: vegetable, fruit or wine? Atherosclerosis. 2000;153:107-117.

Sachinidis A, Skach RA, Seul C, Ko Y, Hescheler JR, Ahn HY, Fingerle JR. Inhibition of the PDGF $\beta$-receptor tyrosine phosphorylation and its downstream intracellular signal transduction pathway in rat and human vascular smooth muscle cells by different catechins. FASEB J. 2002; 16:893-895.

Sadava D, Whitlock E, Kane SE. The green tea polyphenol, epigallocatechin-3-gallate inhibits telomerase and induces apoptosis in drug-resistant lung cancer cells. Biochem Biophys Res Commun. 2007;360:233-237.

Salah N, Miller NJ, Paganga G, Tijburg L, Bolwell GP, RiceEvans C. Polyphenolic flavanols as scavengers of aqueous phase radicals and as chain-breaking antioxidants. Arch Biochem Biophys. 1995;322:339-346.

Sanae F, Miyaichi Y, Kizu H, Hayashi H. Effects of catechins on vascular tone in rat thoracic aorta with endothelium. Life Sci. 2002;71:2553-2562.

Sanna B, Bueno OF, Dai YS, Wilkins BJ, Molkentin JD. Direct and indirect interactions between calcineurin-NFAT and MEK1- extracellular signal-regulated kinase 1/2 signaling pathways regulate cardiac gene expression and cellular growth. Mol Cell Biol. 2005;25:865-878.

Santangelo C, Vari R, Scazzocchio B, Di Benedetto R, Filesi C, Masella R. Polyphenols, intracellular signalling and inflammation. Ann Ist Super Sanita 2007;43:394-405.

Seeram NP, Zhang Y, Nair MG. Inhibition of proliferation of human cancer cells and cyclooxygenase enzymes by anthocyanidins and catechins. Nutr Cancer. 2003;46:101-106.

Shay JW, Zou Y, Hiyama E, Wright WE. Telomerase and cancer. Hum Mol Genet. 2001;10:677-685. 
Shimizu M, Deguchi A, Lim JT, Moriwaki H, Kopelovich L, Weinstein IB. (-)-Epigallocatechin gallate and polyphenon E inhibit growth and activation of the epidermal growth factor receptor and human epidermal growth factor receptor-2 signaling pathways in human colon cancer cells. Clin. Cancer Res. 2005;11:2735-2746.

Shukitt-Hale B, Lau FC, Joseph JA. Berry Fruit Supplementation and the Aging Brain. J Agric. Food Chem. 2008;56:636-641.

Shukitt-Hale B, Mouzakis G, Joseph JA. Psychomotor and spatial memory performance in aging male Fischer 344 rats. Exp Gerontol. 1998;33:615-624.

Shukitt-Hale B. The effects of aging and oxidative stress on psychomotor and cognitive behavior. Age. 1999; 22:9-17.

Smith CD, Carney JM, Starke-Reed PE, Oliver CN, Stadtman ER and Floyd RA. Excess brain protein oxidation and enzyme dysfunction in normal aging and in Alzheimer disease. Proc Natl Acad Sci USA. 1991;88:10540-10543.

Son DJ, Cho MR, Jin YR, Kim SY, Park YH, Lee SH, Akiba S, Sato T, Yun YP. Antiplatelet effect of green tea catechins: a possible mechanism through arachidonic acid pathway. Prostaglandins Leukot Essent Fatty Acids. 2004;71:25-31.

Song DU, Jung YD, Chay KO, Chung MA, Lee KH, Yang SY, Shin BA, Ahn BW. Effect of Drinking Green Tea on AgeAssociated Accumulation of Maillard-Type Fluorescence and Carbonyl Groups in Rat Aortic and Skin Collagen. Arch Biochem Biophys. 2002;397:424-429.

Stangl V, Dreger H, Stangl K, Lorenz M. Molecular targets of tea polyphenols in the cardiovascular system. Cardiovasc Res. 2007;73:348-358.

Starke-Reed PE, Oliver CN. Protein oxidation and proteolysis during aging and oxidative stress. Arch Biochem Biophys. $1989 ; 275: 559-567$.

Steinberg D, Parthasarathy S, Carew TF, Khoo JC, Witztum JL. Beyond cholesterol. Modifications of low-density lipoprotein that increases its atherogenicity. N Engl J Med. 1989;320:915924.

Subramanian N, Venkatesh P, Ganguli S, Sinkar VP. Role of polyphenol oxidase and peroxidase in the generation of black tea theaflavins. J Agric Food Chem. 1999;47:2571-2578.

Suganuma M, Okabe S, Oniyama M, Tada Y, Ito H, Fujiki H. Wide distribution of $[3 \mathrm{H}](-)$-epigallocatechin gallate, a cancer preventive tea polyphenol, in mouse tissue. Carcinogenesis. 1998;19:1771-1776.

Sugisawa A, Kimura M, Fenech M, Umegaki K. Antigenotoxic effects of tea catechins against reactive oxygen species in human lymphoblastoid cells. Mutat Res. 2004;559:97-103.

Sutherland BA, Rahman RM, Appleton I. Mechanisms of action of green tea catechins, with a focus on ischemia-induced neurodegeneration. J Nutr Biochem. 2006;17:291-306.

Tournaire C, Croux S, Maurette MT, Beck I, Hocquaux M, Braun AM, Oliveros E. Antioxidant activity of flavonoids:
Efficiency of singlet oxygen $(1 \Delta \mathrm{g})$ quenching. J Photochem Photobiol B. 1993; 19:205-215.

Upaganlawar A, Balaraman R. Effect of vitamin E and green tea on hemodynamic, electrocardiographic and some biochemical alterations in experimentally induced myocardial infarction in rats. Eur J Integrative Med. 2010;2:135-141.

van Acker SA, van den Berg DJ, Tromp MN, Griffioen DH, van Bennekom WP, van der Vijgh WJ. Bast A. Structural aspects of antioxidant activity of flavonoids. Free Radic Biol Med. 1996;20:331-342.

Velayutham P, Babu A, Liu D. Green Tea Catechins and Cardiovascular Health: An Update. Curr Med Chem. 2008; 15:1840-1850.

Verma S, Yeh ET. C-reactive protein and atherothrombosisbeyond a biomarker: an actual partaker of lesion formation. Am J Physiol Regul Integr Comp Physiol. 2003;285:R1253-1256.

Virmani R, Avolio AP, Mergner WJ, Robinowitz M, Herderick EE, Cornhill JF, Guo SY, Liu TH, Ou DY, O'Rourke M. Effect of aging on aortic morphology in populations with high and low prevalence of hypertension and atherosclerosis: comparison between occidental and Chinese communities. Am J Pathol. 1991;139:1119-1129.

Vlassara H, Bucala R, Striker L. Pathogenic effects of advanced glycosylation: biochemical, biologic, and clinical implications for diabetes and aging. Lab Inves. 1994;70:138151.

Wakai K, Ohno Y, Obata K, Aoki K: Prognostic significance of selected lifestyle factors in urinary bladder cancer. Jpn J Cancer Res. 1993;84:1223-1229.

Wang CH, Li SH, Weisel RD, Fedak PW, Dumont AS, Szmitko P, Li RK, Mickle DA, Verma S. C-reactive protein upregulates angiotensin type 1 receptors in vascular smooth muscle. Circulation. 2003;107:1783-1790.

Wang ZY, Huang MT, Lou YR, Xie JG, Reuhl KR, Newmark HL, Ho CT, Yang CS, Conney, AH. Inhibitory effects of black tea, green tea, decaffeinated black tea, and decaffeinated green tea on ultraviolet B light-induced skin carconogenesis in 7,12dimethylbenz[a]anthracene-initiated SKH-1 mice. Cancer Res. 1994;54:3428-3435.

Wang ZY, Khan WA, Bickers DR and Mukhtar H. Protection against polycyclic aromatic hydrocarbon-induced skin tumor initiation in mice by green tea polyphenols. Carcinogenesis. 1989;10:411-415.

Weinreb O, Mandel S, Amit T, Youdim MB. Neurological mechanisms of green tea polyphenols in Alzheimer's and Parkinson's diseases. J Nutr Biochem. 2004;15:506-516.

West RL. An application of pre-frontal cortex function theory to cognitive aging. Psychol Bull. 1996;120:272-292.

Wiseman H, Halliwell B. Damage to DNA by reactive oxygen and nitrogen species: role in inflammatory disease and progression to cancer. Biochem J. 1996;313:17-29. 
Wolff VJ, Freshman M. Age-related reduction of the RNA content of rat cardiac muscle and cerebellum. Arch Biochem Biophys. 1961;95:181-182.

Xu Y, Ho CT, Amin SG, Han C, Chung FL. Inhibition of tobacco-specific nitrosamine-induced lung tumorigenesis in $\mathrm{A} / \mathrm{J}$ mice by green tea and its major polyphenol as antioxidants. Cancer Res. 1992; 52:3875-3879.

Yamamoto A, Shin RW, Hasegawa K, Naiki H, Sato H, Yoshimasu F, Kitamoto T: Iron (III) induces aggregation of hyperphosphorylated tau and its reduction to iron (II) reverses the aggregation: implications in the formation of neurofibrillary tangles of Alzheimer's disease. J Neurochem. 2002; 82:11371147.

Yamane T, Nakatani H, Kikuoka N, Matsumoto H, Iwata Y, Kitao Y, Oya K, Takahashi T. Inhibitory effects and toxicity of green tea polyphenols for gastrointestinal carcinogenesis. Cancer. 1996; 77:1662-1667.

Youdim KA, Joseph JA. A possible emerging role of phytochemicals in improving age-related neurological dysfunctions: a multiplicity of effects. Free Radic Biol Med. 2001;30:583-594.

Youdim MB, Stephenson G, Ben Shachar D. Ironing iron out in Parkinson's disease and other neurodegenerative diseases with iron chelators: a lesson from 6-hydroxydopamine and iron chelators, desferal and VK-28. Ann N Y Acad Sci. 2004;1012:306-325.

Zaveri NT. Green tea and its polyphenolic catechins: Medicinal uses in cancer and noncancer applications. Life Sci. 2006;78:2073-2080.

Zhang G, Miura Y, Yagasaki K. Effects of dietary powdered green tea and theanine on tumor growth and endogenous hyperlipidemia in hepatoma-bearing rats. Biosci Biotechnol Biochem. 2002;66:711-716.

Zhong L, Goldberg MS, Gao YT, Hanley JA, Parent ME, Jin F. A population-based case-control study of lung cancer and green tea consumption among women living in Shanghai, China. Epidemiology. 2001;12:695-700.

Zhou YD, Kim YP, Li XC, Baerson SR, Agarwal AK, Hodges TW, Ferreira D, Nagle DG. Hypoxia-inducible factor-1 activation by (-)-epicatechin gallate: potential adverse effects of cancer chemoprevention with high-dose green tea extracts. J Nat Prod. 2004;67:2063-2069.

Zhu M, Gong Y, Yang Z, Ge G, Han C, Chen J. Green tea and its major components ameliorate immune dysfunction in mice bearing Lewis lung carcinoma and treated with the carcinogen NNK. Nutr Cancer. 1999;35:64-72. 